Available online at: https://proceeding.researchsynergypress.com/index.php/rsfconferenceseries1

RSF Conference Series: Business, Management and Social Sciences

e-ISSN 2807-5803/ p-ISSN 2807-6699

Volume 1 Number 3 (2021): 428-433

\title{
How to Implement SME Empowerment during the Covid-19 Pandemic?
}

\author{
Hendro Widjanarko ${ }^{1}$, Suratna ${ }^{2}$, Humam Santosa Utomo ${ }^{2}$, Tri Wibawa ${ }^{3}$ \\ ${ }^{1}$ Management Department, Universitas Pembangunan Nasional "Veteran" Yogyakarta, Indonesia \\ 2 Business Administration Department, Universitas Pembangunan Nasional "Veteran” Yogyakarta, \\ Indonesia \\ ${ }^{3}$ Industrial Engineering Department, Universitas Pembangunan Nasional “Veteran” Yogyakarta, \\ Indonesia
}

\begin{abstract}
The potential of Gunung Kidul beach tourism is getting bigger with the opening of highway access along the south coast. The existence of this potential is an opportunity for MSMEs in coastal areas to improve community welfare. The author has found a formulation of the SME development strategy based on the results of previous studies with the Gunung Kidul Regional Government and SMEs in the south coast area. The implementation of the partnership strategy has been implemented by the Regional Government, although it is still in the early stages of implementation. This paper reviews the implementation of the SME development strategy during the pandemic implemented by the Gunung Kidul Regional Government. The analytical method used in the research is a qualitative and quantitative analysis by developing various sources of information through focus group discussions, interviews, observations, policy studies, as well as a study of secondary data on SMEs and tourism in Gunung Kidul Regency. SMEs involved in this study consisted of clusters selling fresh fish and culinary delights. The results of the study reveal that strategic issues that have occurred during the pandemic have a negative impact on SMEs. The strategy for empowering SMEs needs to be made several adjustments according to the internal conditions of SMEs and pandemic conditions.
\end{abstract}

Keywords: SME empowerment strategy, COVID-19 pandemic, Gunung Kidul Yogyakarta

This is an open access article under the CC-BY-NC license

\section{INTRODUCTION}

The poverty rate in Gunung Kidul Regency is still relatively high, so a breakthrough is needed to improve people's living standards. The potential for south coast tourism is very high so that it can be developed to increase the income of MSMEs so that the implementation of the MSME development strategy becomes a priority for poverty alleviation. Poverty alleviation is one of the research focuses of UPN "Veteran" Yogyakarta, as stated in the 2020-2024 research strategic plan. UPN "Veteran" Yogyakarta and the local government of Gunung Kidul Regency have committed to work together on poverty alleviation programs through the MoU signed on 16 June 2016 (attached).

The research team, together with Bappeda Gunung Kidul, have conducted a study on strategies to increase MSMEs in coastal areas, and the strategy formulation has been obtained. The implementation of the partnership strategy was carried out in 2018 by involving all stakeholders consisting of local governments, banks as creditors, regional companies for CSR programs, coastal tourism Pokdarwis associations, merchant groups, and universities. Strategy implementation requires a study of success and failure. Therefore, this research is directed to evaluate, map the opportunities for success and failure of the

Corresponding author

Hendro Widjanarko, hendro.widjanarko@upnyk.ac.id

DOI: https://doi.org/10.31098/bmss.v1i3.372

Research Synergy Foundation 
strategy, analyze the role of each stakeholder, and measure success. Scientific studies are needed to evaluate the implementation of strategies which include evaluating the optimization of the role of stakeholders, compiling a correction plan, measuring benefits for MSMEs, and compiling a more professional MSME development plan as part of the tourism element in serving tourists.

The formulation of the research problem is as follows:

1. What are the strategic issues that have developed in implementing strategies during the pandemic?

2. How is the strategy for SME empowerment to be adjusted during the pandemic?

\section{LITERATURE REVIEW}

Porter (1980) reveals that in building a strategy, several strengths that must be created include: 1) Overall cost advantage; 2) Differentiation; and 3) Focus on a specific buyer group, product line segment, or geographic market. The MSME development strategy must also rely on these three pillars so that it has a high competitive advantage. Competition between MSMEs is a natural thing, but if synergistic cooperation occurs, it will produce mutual strength.

Resource Base Theory analyzes and interprets organizational resources to understand how the organization achieves a sustainable competitive advantage so as to achieve the set performance. RBV focuses on the concept of firm attributes that are difficult to imitate as a source of superior performance and competitive advantage (Barney, 1991). The natural uniqueness of the south coast can be used as an advantage for SMEs. For example, SMEs culinary fish in the southern coast of Gunung Kidul. The cheapness of various types of marine fish catches provides high competitiveness with various types of fish that are sold at lower prices. This is an advantage that needs to be explored.

Stakeholder theory (Freeman, 1984) asserts that the existence of an organization depends on stakeholders. Thus, the existence of MSMEs in coastal areas requires attention and empowerment from various stakeholders, including the government, companies, banks, trade associations, and universities. The synergy pattern is built to improve the performance and independence of MSMEs in a sustainable manner.

Abosede et al. (2016) and Omsa et al. (2017) found that SME empowerment programs require strategic planning, which includes SWOT analysis and strategy formulation. The development of MSMEs in developing countries that is not preceded by a SWOT analysis does not have an effect on the performance and independence of MSMEs. These results indicate the importance of strategic planning before the implementation of MSME development is carried out. This means that the development of MSMEs must be based on internal (SW) and external (OT) analysis. Technology is often an obstacle in the development of MSMEs (Yanes-Estévez et al. 2018)

Sandada et al. (2014) found that strategic planning is needed in managing MSME groups. Evidence shows the importance of strategic management in empowering MSMEs in South Africa. Strategic management is able to improve the performance of MSMEs and strengthen their independence of MSMEs. Alenzy (2018) found that the government is very important in the strategic planning of MSMEs,

Ali and Wang Qun (2019) have also identified a relationship between strategic management practices and the performance of SMEs operating in Bangladesh. Three variables covering strategy formulation, strategy implementation, and strategy evaluation have been developed. The results of the study reveal that strategy formulation, strategy implementation, and strategy evaluation affect the performance of SMEs. The results of this study indicate the importance of strategic management in improving the performance of SMEs. 
Williams et al. (2019) outline the importance of strategic management in the development of MSMEs. Some important things in the practice of MSME development strategies are entrepreneurial orientation, strategic planning, goal setting, total quality management, social capital, and analysis of small business owners' financial ratios. Therefore, these things are very important in improving the performance of independence, the competitiveness of SMEs (Nohong et al., 2018). The results of Pournasir's (2013) research have also identified the success factors for implementing the MSME strategy in Iran.

Table 1. Research Results from the Relevant Proposing Team

\begin{tabular}{cll}
\hline No. & \multicolumn{1}{c}{ Author } & \multicolumn{1}{c}{ Relevant Research Findings } \\
\hline 1. & $\begin{array}{l}\text { Supardi, Hendro Widjanarko, } \\
\text { Tri Wibawa, Puryani (2014) }\end{array}$ & $\begin{array}{l}\text { The development of the silver industry (creative } \\
\text { industry) must be supported by a tourism strategy in } \\
\text { Yogyakarta. }\end{array}$ \\
\hline 2. & Susanta dan Suratna (2014) & $\begin{array}{l}\text { Synergy is needed between the community, SMEs, and } \\
\text { the government in developing tourism potential }\end{array}$ \\
\hline 3. & $\begin{array}{l}\text { Hendro Widjanarko, Tri } \\
\text { Wibawa (2015) }\end{array}$ & $\begin{array}{l}\text { The importance of market access in the development of } \\
\text { SMEs }\end{array}$ \\
\hline 4. & Suratna (2016) & SWOT-based SME development pattern \\
\hline
\end{tabular}

Based on theoretical studies and up-to-date research results, including the research results of the proposers, it can be used as a reference in analyzing the implementation of the SME development strategy that has been determined previously, namely the partnership strategy. The partnership strategy was chosen to improve performance and independence and avoid unfavorable competition among SMEs.

\section{RESEARCH METHOD}

This type of research is applied research, namely, analyzing the implementation of the MSME development strategy that has been designed previously. The approach used is qualitative. This approach is relevant to measure the perceptions and answers of each informant to be interpreted with the support of quantitative data in the form of SME performance achievements. The research location is in Gunung Kidul Regency, Yogyakarta Special Region. The location is focused on coastal SMEs in Kepanewon Panggang and Kepanewon Saptosari. The informants of this research are stakeholders related to the MSME development program in the southern coastal area, including 1) the Regent of Gunung Kidul and the ranks of the local government; 2) Companies that provide CSR; 3) Banks that disburse soft loans are BRI and BPD-DIY; 4) Coastal tourism managers in Gunung Kidul/Pokdarwis, and 5) Gunung Kidul Coastal SME Association. Data collection methods in this study were using open questionnaires, in-depth interviews, FGDs, and documentation. Triangulation was used to test the validity of the data obtained. Data analysis used the descriptive analysis method by describing the data obtained from the field related to the problems raised in this study and then drawing conclusions.

\section{FINDINGS AND DISCUSSION}

The research data collection involved elements of the Gunung Kidul Regency Government, the Krambil Sawit Village Government, the Head of Bedalo Hamlet, Pokdarwis, and business actors (UKM) on the coast of Gunung Kidul, which are managed by the community. The results of this study can be summarized as follows: 


\section{Strategic Issues}

The strategic issues that will develop in 2021 are as follows:

\section{Covid-19 pandemic}

The COVID-19 pandemic has occurred since 2020 until this research report was prepared. The number of people infected with the Covid-19 virus is increasing so that the number of victims is also increasing. Although the number of victims in Gunung Kidul Regency is relatively small compared to other cities/districts in DIY, the increase is even higher. As a result of the pandemic, of course, it affects the amount of revenue for the Gunung Kidul Regional Government. In addition, more government spending is allocated to deal with the pandemic.

\section{Restriction Policy}

Regional restrictions were imposed by the government to break the chain of the spread of the COVID-19 virus. The PPKM adopted by the Central Government is also implemented in the Gunung Kidul area. As a result, the movement of people from one region to another is not flexible compared to normal times.

\section{Less Contact Economy}

The regional restriction policy due to the spread of COVID-19 has implications for low direct contact. Business activities are carried out remotely without going through physical contact. This becomes a significant difficulty for entrepreneurs who rely on direct relationships such as culinary stalls. However, entrepreneurs can take advantage of information technology via the internet to inform the public of their products.

\section{Industrial Revolution 4.0}

The era of the Industrial Revolution 4.0 was marked by the role of technology taking over most of the community's activities. Communication and information technology increases connectivity, interaction, boundaries between humans, machines, and other resources increasingly converge. The fourth industrial revolution is marked by the optimal use of information and communication technology, not only limited to the production process but also throughout the industrial chain so as to produce a new digital-based business model. All of these processes create high efficiency and higher quality products. In the business sector, information technology makes it easier for business people to run their businesses. Entrepreneurs can access consumers all over the world. Writers can also leverage technology to deliver products to consumers accurately. However, the speed of information is also a challenge for entrepreneurs. Information on consumer dissatisfaction will quickly reach the wider community so that it can reduce credibility. The quality of products and services must really be sought so that consumers feel satisfied.

\section{Adjustment of the SME Development Strategy in the Coastal Tourism Area of Gunung Kidul Regency, Yogyakarta}

The external environment is changing very quickly due to the COVID-19 pandemic situation. Therefore some strategies and implementations need adjustments and additions. The following are recommended strategies and implementations during a pandemic. 
Improving the quality of SME human resources to face the New Normal

- Fintech training for SMEs

- Digital marketing training

- Technical training on preserving marine products (fish, seaweed, etc.)

- Online transaction and product delivery training

Improved beach infrastructure

- Development of internet facilities

- Online-based infrastructure development (visitor density information, inafis, online tickets)

Improved facilities provided for coastal SMEs

- Wi-fi facilitation

- The place to sell is far away

- Handwashing facilities

- Temperature test facility

Improved marketing communication

- Making online promotions through the website by adding menus needed during the pandemic

- Making social media advertising such as youtube, Facebook, Instagram, and others.

Improving SME services to visitors

- Preparation of SME service standards for visitors by implementing health protocols

- Providing medical personnel around the beach location

Improving the financial capacity of SMEs

- Access to financial institutions with soft credit is still required

Increased stakeholder engagement.

- Create a virtual stakeholder communication forum.

- Involvement of stakeholders in formulating policies related to the development of coastal SMEs.

\section{CONCLUSION AND FUTURE RESEARCH}

The results of the study reveal that strategic issues that have occurred during the pandemic have a negative impact on SMEs. The policy of limiting interaction causes a decrease in the number of consumers, thereby weakening the ability of SMEs to generate profits. Stakeholders need to adjust SME empowerment strategies according to the internal conditions of SMEs and pandemic conditions. Empowerment strategies are more directed at increasing the ability of SMEs the use online-based technology. Further research is recommended to examine the factors that affect the performance of SMEs during the pandemic.

\section{REFERENCES}

Alenzy, M.Z. 2018. Strategic Approach of Saudi Small and Medium-Sized Enterprises: More of Emergent or Deliberate?. International Business Research; Vol. 11, No. 3; 2018 ISSN 1913-9004 E-ISSN 1913-9012 Published by Canadian Center of Science and Education 
Ali, M. 2019. Strategic Management Practices and Performance of The Sme's in Bangladesh. Int. J. Adv. Res. 7(1), 69-78 DOI URL: http://dx.doi.org/10.21474/IJAR01/8298

David, F.R. 2016. Strategic Management. Pearson College Division Published

Gure, A.K. and Karugu, J. 2018. Strategic Management Practices and Performance of Small and Micro Enterprises in Nairobi City County, Kenya. International Academic Journal of Human Resource and Business Administration Volume 3, Issue 1, pp. 1-26

Nohong, M. Sanusi, A., Nurqamar, I.F., Haru, S. 2018. Strategic Model in Increasing the SMEs Competitive Advantage in South Sulawesi. International Journal of Administrative Science \& Organization International Journal of Administrative Science \& Organization, May 2018, Volume 25, Number 2

Omsa, S., Ridwan, M., Jayadi, M.. 2017. The Effect of Strategic Management Practices on SME Performances in Makassar, Indonesia. American Journal of Theoretical and Applied Business 2017; 3(4): 71-80 http://www.sciencepublishinggroup.com/j/ajtab doi: 10.11648/j.ajtab.20170304.12

Porter, Michael E. 1980. Strategi Bersaing, Jakarta : Erlangga

Pournasir, S. 2013. Key Success Factors of Strategic Management Implementation in SMEs in Iran. Journal of International Studies, Vol 6 No. 2. DOI: 10.14254/2071-8330.2013/6-2/6

Sandada, M., Pooe, D., and Dhurup, M. 2014. Strategic Planning And Its Relationship With Business Performance Among Small And Medium Enterprises In South Africa. International Business \& Economics Research Journal - May/June 2014 Volume 13, Number 3

Utomo, HS. 2020. The Effect of Muslim Religiosity and Innovation Capability on Firm Survival: A Study on Small Enterprises During the Covid-19 Pandemic. IQTISHADIA Vol. 13 (2) 2020 PP. 179-196 DOI : 10.21043/iqtishadia.v13i2.7626

Williams Jr., R.I., Smith, A., Aaron, J.R., Manley, S.C., McDowell, W.C. 2019. Small business strategic management practices and performance: A configurational approach. Economic Research-Ekonomska Istraživanja, 33:1, 2378-2396, DOI: 10.1080/1331677X.2019.1677488

Yanes-Estévez, V., García-Pérez, AM. and Oreja-Rodríguez, J.R. 2018. The Strategic Behaviour of SMEs. Adm. Sci. 2018, 8, 61; doi:10.3390/admsci8040061 www.mdpi.com/journal/admsci 